\title{
ANALISIS KUALITAS PRODUK, HARGA DAN PROMOSI TERHADAP KEPUTUSAN PEMBELIAN MINYAK RAMBUT POMADE GATSBY PADA MAHASISWA FAKULTAS EKONOMI UNES-AAI
}

\author{
Yulistia \\ Dosen Fakultas Ekonomi Univeristas Ekasakti, Padang
}

\begin{abstract}
This research aims to determine whether there is an influence of product quality, price, and promotion on the decision to purchase Gatsby pomade products. The data collection method used in this research is by using a questionnaire, which is a data collection technique that is carried out by giving a set of questions or statements to students of the economic faculties of Unes-AAI.2017-2018 who use Gatsby pomade products. The method of data analysis in this study used multiple linear regression. The results of this study indicate that: 1) Based on the t test it is known that the variables of Product Quality, Price, and Promotion have a significant effect on Purchasing Decisions because the calculated tvalue is greater than t table and the sig value is smaller than the probability. 2) Based on the F test it is known that the Product Quality, Price, and Promotion variables together have a significant effect on Purchasing Decisions because the calculated $F$ value is greater than $F$ table and the sig value is smaller than the probability. 3) The results of the analysis of determination obtained the Adjusted R Square number of 0.624. This shows the percentage of product quality variables, prices, and purchasing decisions, in explaining the variance of the Purchase Decision variable is $59.8 \%$. While the remaining $40.2 \%$ is influenced by other variables outside of this study such as brands, places etc.
\end{abstract}

Keywords: Product, Price, Promotion and Purchase Decision

\begin{abstract}
Abstrak: Penelitian ini bertujuan untuk mengetahui apakah terdapat pengaruh kualitas produk, harga, dan promosi terhadap keputusan pembelian produk pomade Gatsby. Metode pengumpulan data yang digunakan dalam penelitan ini yaitu dengan menggunakan angket,yaitu teknik pengumpulan data yang dilakukan dengan cara memberikan seperangkat pertanyaan atau pernyataan kepada mahasiswa fakultas ekonomi Unes-AAI Ta.2017-2018 yang memakai produk pomade Gatsby. Metode analisis data dalam penelitian ini menggunakan regresi linier berganda. Hasil penelitian ini menunjukka bahwa: 1) Berdasarkan uji t diketahui variabel Kualitas Produk, Harga, dan Promosi berpengaruh signifikan terhadap Keputusan Pembelian karena nilai t hitung lebih besar dari $t$ tabel dan nilai sig lebih kecil dari probabilitas. 2) Berdasarkan uji F diketahui variabel Kualitas Produk, Harga, dan Promosisecara bersama sama berpengaruh signifikan terhadap Keputusan Pembelian karena nilai $\mathrm{F}$ hitung lebih besar dari $\mathrm{F}$ tabel dan nilai sig lebih kecil dari probabilitas. 3) Hasil analisis determinasi diperoleh angka Adjusted R Square sebesar 0,624. Hal ini menunjukan persentase kemampuan variabel Kualitas Produk, Harga, dan Keputusan Pembelian, dalam menjelaskan varians dari variabel Keputusan Pembelian adalah sebesar 59,8\%. Sedangkan sisanya sebesar $40,2 \%$ dipengaruhi oleh variabel lain diluar penelitian ini seperti merek, tempat dan lain-lain.
\end{abstract}

Kata Kunci: Produk, Harga, Promosi dan Keputusan Pembelian 


\section{Pendahuluan}

Perilaku kaum pria sekarang ini begitu peka terhadap fashion yangmenunjukkan bahwa pria sekarang memiliki kesadaran akan kebutuhan fashion yang tinggi. Kesadaran fashion pada kaum pria salah satunya ditujukan dengan antusias mereka terhadap produk kosmetik perawatan rambut. Gaya rambut merupakan bagian dalam fashionyang diminati kaum pria saat ini, dimana gayarambut akan mempengaruhi kepribadian dan kepercayaan diri seseorang. Dalam pemilihan gaya rambut yang tepat merupakan hal terpenting bagi seorang pria dalam berpenampilan. Salah satu produk yang saat ini sedang naik daun dan mengalami peningkatan permintaan yang cukup pesat adalah minyak rambut dengan jenis pomade. . Saat ini pomade kembali menjadi tren di kalangan anak muda sebagai salah satu produk fashion yang banyak dipakai dalam penampilan gaya rambut. Meningkatnya permintaan jenis minyak rambut tersebut tidak lepas dari kembali nge-trennya gaya rambut pompadour atau undercut selama kurang lebih 3 tahun terakhir. Pompadour atau undercut adalah sebuah gaya rambut laki-laki dengan teknik sisir rambut yang ditarik rapih kebelakang dengan bagian samping dipotong tipis serta ditambah dengan penggunaan pomade untuk menampilkan kesan klimis dan basah alami. Tren gaya rambut tersebut dipicu oleh menjamurnya barber shop yang membawa budaya rockabilly dari California

Jenis produk Pomade yaitu Gatsby Pomade adalah salah satu produk penata rambut pria yang paling dikenal, karena produk penata rambut ini sudah dikenal dari jaman dahulu era tahun 1970-an. Gatsby Styling Pomade adalah salah satu produk minyak rambut dari PT Mandom Indonesia Tbk. Minyak rambut dengan merek dagang Gatsby dinilai sukses menguasai pangsa pasar di Indonesia. Hal tersebut dibuktikan dengan suksesnya produk tersebut menempati posisi pertama dalam top brand award dalam beberapa tahun terakhir. Begitu juga fenomena yang terjadi pada mahasiwa Unes-AAI Padang yang sadar terhadap desain baru, perubahan mode, dan gaya yang menarik, serta keinginan untuk membeli sesuatu yang menarik dan trendi. Sehingga mereka juga tertarik untuk membeli dan menggunakan produk Pomade Gatsby demi mengikuti tren masa kini untuk penampilan. Berdasarkan pra-penelitian yang dilakukan oleh peneliti, Gatsby Pomade sangat banyak digunakan oleh Mahasiswa Fakultas Ekonomi Universitas Ekasakti-AAI sebagai solusi untuk menjaga tampilan rambut mereka agar tetap tertata rapi.

Hasil penelitian terdahulu yang dilakukan (Argo Lumaksana,2018), tentang kualitas produk, citra merek, harga dan selebriti pendukung memberikan pengaruh signifikan positif terhadap keputusan pembelian minyak rambut Gatsby Styling Pomade pada mahasiswa Fakultas Ekonomi dan Bisnis Islam IAIN Tulungagung. Penelitian yang dilakukan (Fitri Yanti,2017), adanya pengaruh positif promosi dan harga terhadap keputusan pembelian viva kosmetik pada mahasiswa Fakultas Ekonomi dan Bisnis Universitas Muhammadiyah Palembang. Penelitian yang dilakukan Fitri Yanti dengan produk yang berbeda tetapi bisa menjadi acuan dimana promosi dan harga berpengaruh positif terhadap keputusan pembelian oleh mahasiswa. Berdasarkan hal tersebut diatas, maka dapat dirumuskan masalah : Apakah kualitas produk, harga dan promosi berpengaruh terhadap keputusan pembelian Pomade Gatsby pada mahasiswa Fakultas Ekonomi UNES-AAI baik secara parsial dan simultan. Adapun tujuan dari penelitian ini adalah untuk mengetahui: Apakah kualitas produk, harga dan promosi berpengaruh terhadap keputusan pembelian Pomade Gatsby pada mahasiswa Fakultas Ekonomi UNES-AAI.

\section{Landasan teori}

\subsection{Pemasaran}

Pemasaran menurutKotler dan Armstrong (2014:27) adalah proses dimanaperusahaanmenciptakan nilai bagi pelanggan dan membangun hubungan yang kuat dengan pelanggan, dengan tujuan menangkap nilai dari pelanggan sebagaiimbalannya. Menurut Hasan (2013:4), Pemasaran adalah proses mengidentifikasi, menciptakan dan mengkomunikasikan nilai, serta memelihara hubungan 
yang memuaskan pelanggan untuk memaksimalkan keuntungan perusahaan. Dapat disimpulkan pendapat kedua ahli tersebut bahwa pemasaran adalah suatu proses sosial atau fungsi organisasi dalam kegiatan bisnis yang bertujuan untuk menyalurakan atan mendistribusikan barang-barang dalam rangka memuaskan kebutuhan konsumen.

\subsection{Kualitas Produk}

Dewasa ini para konsumen sangatlah kritis dalam memilih suatu produk, keputusan untuk membeli suatu produk sangat dipengaruhi oleh penilaian terhadap kualitas produk tersebut. Menurut William E. Deming dalam Fandy Tjiptono, kualitas produk merupakan suatu tingkat yang dapat diprediksi dari keseragaman dan ketergantungan pada biaya yang rendah dan sesuai dengan pasar. Kotler dan Keller yang dialih bahasakan oleh Bob Sabran (2012 : 143), menyatakan bahwa kualitas produk adalah kemampuan suatu barang untuk memberikan hasil atau kinerja yang sesuai bahkan melebihi dari apa yang diinginkan pelanggan. Kepuasan konsumen terhadap suatu produk berkaitan erat dengan kualitas atau mutu dari produk yang dibutuhkan. Seorang konsumen akan merasa produk yang dibelinya berkualitas apabila produk tersebut dapat memenuhi keinginan dan kebutuhan sesuai dengan yang diharapkan atau melebihi apa yang diharapkan. Setiap perusahaan atau produsen harus memiliki kualitas yang akan memantau atau menunjang untuk meningkatkan atau mempertahankan posisi produknya di pasar.

\subsection{Harga}

Selain kualitas produk, harga juga menjadi salah satu faktor konsumen untuk melakukan keputusan pembelian. Harga adalah salah satu unsur bauran pemasaran yang menghasilkan pendapatan, unsurunsur lain menghasilkan biaya. Menurut Kotler dalam M. Taufiq Amir, harga dapat diartikan sebagai jumlah keseluruhan nilai yang dipertukarkan konsumen untuk manfaat yang didapatkan atau digunakan atas produk dan jasa. Di masa lalu hingga saat ini, harga telah menjadi faktor penting yang mempengaruhi pilihan pembeli. Menurut Kotler dan Armstrong (2012:151), Sejumlah uang yang dibebankan atas suatu barang atau jasa atau jumlah dari nilai uang yang ditukar konsumen atas manfaat-manfaat karena memiliki atau menggunakan produk atau jasa tersebut Dari definisi diatas, kebijakan mengenai harga sifatnya hanya sementara, berarti produsen harus mengikuti perkembangan harga dipasar dan harus mengetahui posisi perusahaan dalam situasi pasar secara keseluruhan.

\subsection{Promosi}

Promosi adalah salah satu bentuk dari kegiatan pemasaran. Promosi merupakan arus informasi atau persuasi satu arah yang dibuat untuk mengarahkan dan mempengaruhi individu atau kelompok kepada tindakan yang menciptakan pertukaran dalam pemasaran. Iklan merupakan salah satubentuk promosi yang paling sering digunakan oleh perusahaan dalam rangka mengenalkan produknya kepada konsumen. MenurutHermawan (2012:38) pengertian promosi adalah, "Promosi adalah salah satu komponen prioritas dari kegiatan pemasaran yang memberitahukan kepada konsumen bahwa perusahaan meluncurkan produk baru yang menggoda konsumen untuk melakukan kegiatan pembelian". Sedangkan menurut Daryanto (2011:94), pengertian promosi adalah "Promosi adalah kegiatan terakhir dari marketing mix yang sangat penting karena kebanyakanpasar lebih banyak bersifat pasar pembeli dimana keputusan terakhir terjadinya transaksi jual beli sangat dipengaruhi oleh konsumen".

\subsection{Keputusan Pembelian}

Keputusan pembelian adalah suatu tindakan yang dilakukan konsumen dalam menggunakan produk yang ditawarkan oleh perusahaan untuk membuat keputusan dalam pembelian suatu produk tertentu 
(Wengan dan Mandey. 2014). Menurut Winardi (2010:200) menyatakan keputusan pembelian konsumen merupakan titik suatu pembelian dari proses evaluasi. Sedangkan menurut Kotler dan Keler $(2009 ; 188)$ keputusan pembelian adalah suatu tindakan konsumen untuk membeli satu merek dari beberapa merek yang terencana, berdasarkan beberapa faktor diantaranya waktu pembelian, kualitas produk, penyalur, dan distributor serta banyak yang lain.

\subsection{Kerangka Pikir}

Dari kajian teori dan hasil penelitian terdahulu diatas maka dapat dibuat kerangka pemikiran penelitian ini seperti yang terlihat pada gambar 1 .

\section{Gambar 2.1 \\ Kerangka Pemikiran}

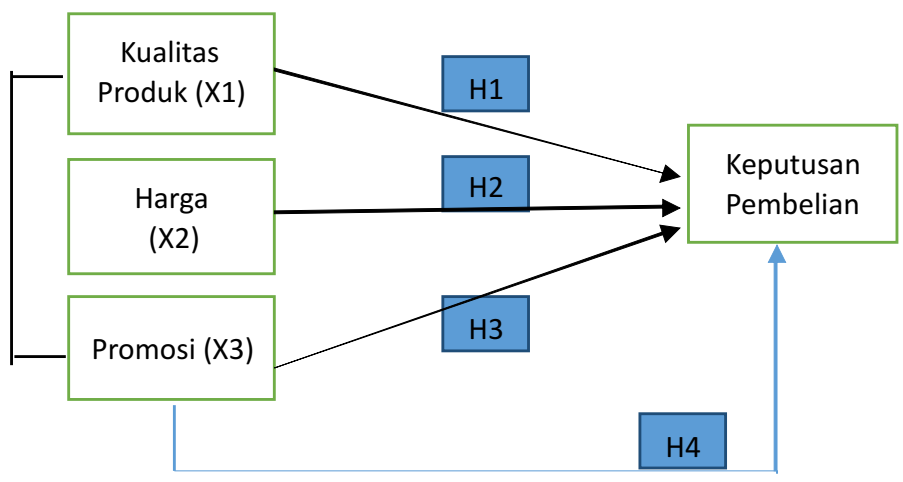

\subsection{Hipotesis}

Berdasarkan gambar 1dapat di rumuskan hipotesis sebagai berikut: "Diduga kualitas produk, harga dan promosi memiliki pengaruh yang signifikan terhadap keputusan pembelian minyak rambut Pomade Gatsby" secara parsial dan simultan.

\section{Metodologi Penelitian}

Metode penelitian merupakan seperangkat cara yang sistimatik, logis dan rasional yang digunakan dalam penelitian ini ketika merencanakan, mengumpulkan, menganalisis dan menyajikan data untuk menarik kesimpulan. Penelitian ini menggunakan metode penelitian survay, dimana metode penelitian survay menurut Sugiyono (2011:6) digunakan untuk mendapatkan data dari tempat tertentu yang alamiah (bukan buatan), tetapi peneliti melakukan perlakuan dalam pengumpulan data, misalkan dengan mengedarkan kuesioner, wawancara, terstruktur dan sebagainya. Penelitian ini menggunakan tipe explanatory reseach yaitu penelitian yang menjelaskan kedudukan variabel-variabel yang diteliti serta hubungan antara satu variabel dengan variabel lainnya. Penelitian ini dilakukan pada mahasiswa UNES-AAI yang pernah membeli produk Pomade Gatsbyagar dapat diketahui seberapa besar pengaruh kualitas produk, harga dan promosi terhadap keputusan pembelian produk Pomade Gatsby.

\subsection{Populasi dan sampel}

Populasi dalam penelitian ini adalah berupa data mahasiswa laki-laki Fakultas Ekonomi UNES-AAI yang menggunakan Pomade Gatsby yang diambil mahasiswa tahun ajaran 2017-2018 terdiri dari jurusan Manajemen, Akuntansi dan Manajemen Informatika dan Komputer, dengan teknik pengambilan datanya Simple Random Sampling. Jenis penelitian ini adalah kuantitatif yaitu menjelaskan fenomena yang ada dengan menggunakan angka-angka. Sumber data yang digunakan 
dalam penelitian ini adalag data primer dan data sekunder. Data primer diperoleh langsung dari mahasiswa sesuai dengan variable penelitian, sedangkan data sekunder biasanya berwujud data dokumentasi atau data laporan yang tersedia (Astrid,1998).

\subsection{Teknik Pengumpulan Data}

Kuesioner merupakan teknik pengumpulan data yang efisien bila peneliti tahu pasti apa yang akan diukur dan apa yang diharapkan oleh responden, dalam penelitian ini penulis menggunakan kuesioner sebagai alat pengumpulan data. Pada penelitian ini menggunakan tiga variabel bebas yaitu kualitas produk $\left(\mathrm{X}_{1}\right)$, harga $\left(\mathrm{X}_{2}\right)$, dan promosi $\left(\mathrm{X}_{3}\right)$. Variabel terikatnya keputusan adalah keputusan pembelian (Y).

\subsection{Teknik Analisi Data}

Penelitian ini melihat hubungan yang terjadi independent variable dengan dependent variable melalui korelasi. Derajat atau tingkat hubungan antara dua variabel diukur dengan menggunakan indeks korelasi, yang disebut koefisien korelasi. Dalam penelitian ini digunakan teknik korelasi sederhana dan multiple-regression analysis. Koefisien-koefisien regresi distandarisasikan untuk mengurai hubungan antara dua variabel bebas dan satu variabel terikat. Dalam pengamatan dan penganalisaan serta pengukuran normalitas, setiap faktor akan dilihat hubungan melalui korelasi sederhana. Hubungan variabel bebas dan terikat secara keseluruhan akan ditinjau lebih jauh untuk mengetahui tingkatan korelasi yang multiple.

\section{Analisis dan pembahasan}

\subsection{Analisis}

Metode pengolahan data yang digunakan pada penelitain ini adalah metode analisis deskriptif dan metode analisis inferensial. Metode analisis deskriptif adalah statistik yang digunakan untuk menganalisa data dengan cara mendeskripsikan atau menggambarkan data yang telah terkumpul sebagaimana adanya tanpa bermaksud membuat kesimpulan yang berlaku untuk digeneralisasikan. Termasuk dalam statistik deskriptif antara lain adalah penyiapan data dalam bentuk tabel, grafik, perhitungan median, mean, standart deviasi, perhitungan prosentase, dan lain-lain (Sugiyono, 2009: 207). Adapun untuk kepentingan penelitian ini menggunakan program SPSS for window. Berdasarkan data kualitas produk $\left(\mathrm{X}_{1}\right)$, harga $\left(\mathrm{X}_{2}\right)$, dan promosi $\left(\mathrm{X}_{3}\right)$. Variabel terikatnya keputusan adalah keputusan pembelian (Y).

\subsubsection{Uji Validitas dan Reliabilitas}

Sebelum melakukan penyebaran kuesioner kepada responden, penulis melakukan percobaan penyebaran kuesioner kepada mahasiswa, untuk melakukan pengujian validitas dan reliabelitas. Jika nilai $\mathrm{r}$ hitung yang merupakan nilai dari Corrected Item - Total Correlation $>$ dari $\mathrm{r}$ tabel maka dapat dinyatakan valid. Selanjutnya kuesioner tersebut akan digunakan dalam penelitian. Uji reliabilitas dapat dilakukan secara bersama-sama terhadap seluruh butir pertanyaan untuk lebih dari satu variabel, namun sebaiknya uji reliabilitas dilakukan pada masing-masing variabel pada lembar kerja yang berbeda sehingga dapat diketahui konstruk variabel mana yang tidak reliabel. Realibilitas suatu konstruk variabel dikatakan baik jika memiliki nilai Cronbach's Alpha $>$ dari 0, 60 .

\subsection{Pembahasan}

\subsubsection{Uji Asumsi Klasik}

Dalam melakukan analisa, penulis menggunakan perangkat lunak SPSS. Hasil dari analisa akan dibahas pada bagian berikut: 


\section{Analisis Kuantitatif}

Analisis kuantitatif bertujuan untuk melihat seberapa besar korelasi atau hubungan antara kualitas produk, harga dan promosi terhadap keputusan pembelian minyak rambut Pomade Gatsby. Hasil analisis korelasi dengan menggunakan SPSS versi 22 dapat dilihat pada tabel berikut:

Tabel 4.1

Hasil Analisis Coefficients Korelasi

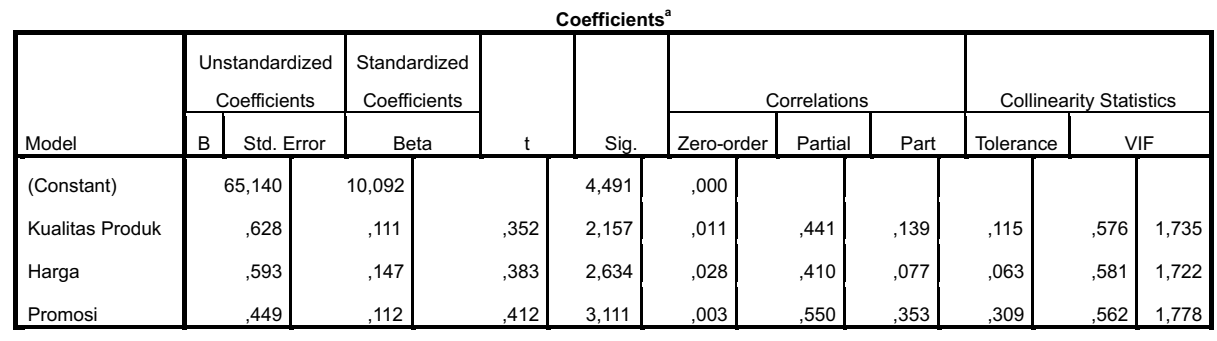

a. Dependent Variable: Keputusan Pembelian

Uji regresi digunakan untuk mengetahui pengaruh antara variabel bebas, yaitu kualitas produk, harga, dan promosi terhadap variabel terikat yaitu keputusan pembelian. Model persamaan regresi yang dapat adalah sebagai berikut:

$\hat{\mathrm{Y}}=\mathrm{a}+\mathrm{b}_{1} \mathrm{X}_{1}+\mathrm{b}_{2} \mathrm{X}_{2}+\mathrm{b}_{3} \mathrm{X}_{3}+\mathrm{e}$

$\hat{Y}=65,140+0,628 X_{1}+0,593 X_{2}+0,449 X_{3}+e$

Berdasarkan tabel 4.1 diatas dapat diinterprestasikan sebagai berikut:

1. Korelasi anatara variabel kualitas produk dengan keputusan pembelian sebesar 0,628 , artinya ini menunjukkan kualitas produk berpengaruh signifikan terhadap keputusan pembelian, hal ini juga menyatakan terdapat korelasi yang sangat kuat antara kualitas produk dengan keputusan pembelian.

2. Korelasi antara harga dengan keputusan pembelian menghasilkan angka 0,593 yang menunjukkan korelasi yang kuatantara harga dengan keputusan pembelian.

3. Korelasi antara promosi dengan keputusan pembelian menghasilkan angka 0,449 yang artinya terdapat korelasi sedang antara promosi dengan keputusan pembelian.

4. Kualitas produk, harga dan promosi memiliki hubungan yang signifikan terhadap keputusan pembelian.

Hasil analisa koefisien korelasi secara ganda atau bersama-sama dapat dilihat pada tabel 2 di bawah ini:

Tabel 4.2

Hasil Analisis Uji R dan $\mathbf{R}^{2}$

Model Summary ${ }^{\mathrm{b}}$

\begin{tabular}{|c|c|c|c|c|c|c|c|c|c|}
\hline \multirow[b]{2}{*}{ Model } & \multirow[b]{2}{*}{$\mathrm{R}$} & \multirow[b]{2}{*}{ R Square } & \multirow[b]{2}{*}{$\begin{array}{l}\text { Adjusted R } \\
\text { Square } \\
\end{array}$} & \multirow[b]{2}{*}{$\begin{array}{l}\text { Std. Error of } \\
\text { the Estimate }\end{array}$} & \multicolumn{5}{|c|}{ Change Statistics } \\
\hline & & & & & $\begin{array}{l}\text { R Square } \\
\text { Change }\end{array}$ & F Change & df1 & df2 & Sig. F Change \\
\hline 1 &, $572^{\mathrm{a}}$ & ,328 & ,598 & 6,57753 & ,328 & 11,047 & 3 & 68 &, 000 \\
\hline
\end{tabular}

a. Predictors: (Constant), Promosi, Harga, Kualitas Produk

b. Dependent Variable: Keputusan Pembelian

Berdasarkan tabel 4.2, nilai $\mathrm{R}$ adalah sebesar 0,572. Hal ini menunjukkan bahwa variabel independent kualitas produksi (X1), harga (X2) dan promosi (X3) terhadap variabel dependent keputusan pembelian memiliki hubungan yang kuat dan nilai koefisien korelasi sebesar 40,2\% dipengaruhi oleh faktor lain. Penelitian ini sejalan dengan penelitian Yogie Alfarizhy (2015) bahwa 
pengaruh kualitas produk dan harga terhadap keputusan pembelian minyak rambut Gatsby pomade pada mahasiswa fakultas ekonomi dan bisnis Universitas Muhammadiyah Palembang, menunjukan adanya pengaruh signikan harga terhadap keputusan pembelian, hal ini berarti harga penting dalam keputusan pembelian karena harga yang layak akan menjadi pertimbangan bagi konsumen dalam melakukan keputusan pembelian. Hal ini juga didukung oleh teori Kotler dan Armstrong yang menyatakan kualitas produk merupakan suatu kemampuan yang bisa dinilai dari suatu produk di dalam menjalankan fungsinya, yang merupakan suatu gabungan dari daya tahan, kendala, ketepatan, kemudian pemeliharaan serta atribut-atribut lainnya dari suatu produk. Pada umumnya barang yang memiliki kualitas bagus yang artinya mampu memenuhi fungsi-fungsi produk dengan baik, maka akan secara otomatis berpengaruh positif terhadap keputusan seorang konsumen dalam membeli suatu produk.

\subsubsection{Hasil Uji Hipotesis}

Pengujian hipotesis bertujuan untuk melihat apakah masing-masing variabel memiliki hubungan yang signifikan atau tidak dengan $\alpha=0,05$. Berdasarkan tabel 1 diatas dapat di interpretasikan sebagai berikut:

1. Nilai probabilitas kualitas produk dengan keputusan pembelian adalah sebesar $0,011<0,05$ artinya terdapat korelasi positif dan signifikan antara kualitas produk dengan keputusan pembelian.

2. Nilai probabiltas harga dengan keputusan pembelian adalah sebesar sebesar $0,028<0,05$, dapat disimpulkan bahwa harga berpengaruh positif dan signifikan terhadap keputusan pembelian

3. Nilai propitabitas promosi dan keputusan pembelian adalah sebesar signifikan sebesar $0,03<$ 0,05 , artinya promosi berpengaruh positif dan signifikan terhadap keputusan pembelian.

4. Nilai propitabilitas kualitas produk, harga dan promosi sebesar sebesar $0,00<0,05$ yang artinya berpengaruh positif dan signifikan secara bersama-sama terhadap keputusan pembelian.

Tabel 4.3

Hasil Analisis Uji t

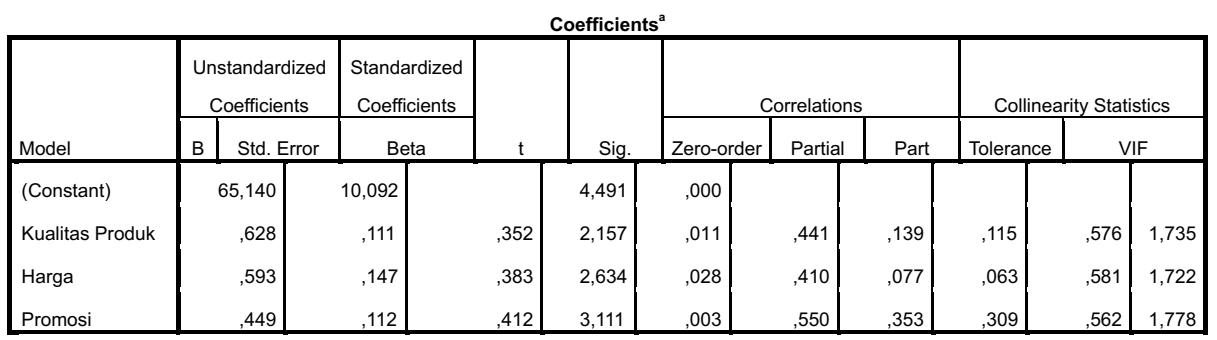

a. Dependent Variable: Keputusan Pembelian

Tabel 4.4

Hasil Analisis Uji F

ANOVA $^{\text {a }}$

\begin{tabular}{|ll|r|r|r|r|r|}
\hline Model & & Sum of Squares & \multicolumn{1}{c|}{ df } & Mean Square & F & \multicolumn{1}{c|}{ Sig. } \\
\hline 1 & Regression & 1433,833 & 3 & 477,944 & 11,047 &, $000^{\mathrm{b}}$ \\
& Residual & 2941,945 & 68 & 43,264 & & \\
& Total & 4375,778 & 71 & & & \\
\hline
\end{tabular}

a. Dependent Variable: Keputusan Pembelian

b. Predictors: (Constant), Promosi, Harga, Kualitas Produk

\section{Simpulan dan Saran}

\subsection{Simpulan}

Berdasarkan hasil penelitian dan pembahasan yang telah dikemukakan sebelumnya, maka di peroleh kesimpulan sebagai berikut: 
1. Hasil uji secara parsial dengan nilai statistik t hitung sebesar 2,157 , oleh karena thitung $>t$ tabel $(2,157>1,99)$ serta nilai probabilitas sebesar $0,011<0,05$, maka Ho di tolak dan Ha di terima yang berarti terdapat pengaruh signifikan dari variabel kualitas produk terhadap keputusan penbelian.

2. Hasil uji secara parsial dengan nilai statistik t hitung sebesar 2,634 , oleh karena thitung $>t$ tebal $(2,634>1,99)$ serta nilai probabilitas sebesar $0,028<0,05$, maka Ho di tolak dan Ha di terima yang berarti terdapat pengaruh signifikan dari variabel harga terhadap keputusan pembelian.

3. Hasil uji secara parsial dengan nilai statistik thitung sebesar 3,111, oleh karena thitung $>\mathrm{t}$ tabel $(3,111>1,99)$ serta nilai probabilitas sebesar $0,003<0,05$, maka Ho di tolak dan Ha di terima yang berarti terdapat pengaruh signifikan dari variabel promosi terhadap keputusan pembelian.

4. Hasil uji secara simultan dengan nilai $F$ hitung sebesar 11,047, oleh karena $F$ hitung $>F$ tebal $(11,047>2,74)$, maka Ho ditolak dan Ha diterima yang berarti terdapat pengaruh signifikan dari variabel kualitas produk, harga, dan promosi secara bersama-sama terhadap variabel keputusan pembelian. Besarnya nilai korelasi $(\mathrm{R})$ sebesar 0,572 yang berarti menunjukan adanya korelasi/hubungan yang sangat kuat antara kualitas produk, harga, dan promosi dengan keputusan pembelian. Besarnya nilai adjusted coeficient of determination $\left(\mathrm{R}^{2}\right)$ adalah 0,598 atau $59,8 \%$ yang berarti variabel-variabel bebas dapat menerangkan perubahan pada variabel keputusan pembelian sebesar 59,8\% sedangkan sisanya sebesar 40,2\% diterangkan oleh faktorfaktor lain diluar penelitian ini.

\subsection{Saran}

Dalam mempertahankan kualitas produk, perusahaan harus mempertahankan produk tersebut dan membuat inovasi produk barang yang memiliki kualitas bagus yang artinya mampu memenuhi fungsi-fungsi produk dengan baik, maka akan secara otomatis berpengaruh positif terhadap keputusan seorang konsumen dalam membeli suatu produk. Dalam promosi perusahaan juga harus lebih sering dilakukan guna untuk mengantisipasi pesaingnya dengan produk yang sama. Sistim penjualan juga harus mengikuti perkembangan zaman yang ada saat ini.

\section{Daftar Pustaka}

Amrullah, Artika Romal. 2016. Pengaruh Kualitas Produk, Harga dan Citra Merek Terhadap Keputusan Pembelian Honda Beat. Jurnal Ilmu dan Riset Manajemen. Vol. 5. No. 7. Surabaya. Astrid, D. 1998. Metode Penelitian (Edisi Pert). Pustaka Pelajar(Anggota IKAPI). Yogyakarta.

Baedowi, Mohammad Maftuh., EishaLataruva (2012). Analisis pengaruh kualitas produk, kesesuain harga dan intensitas promosi terhadap keputusan pembelian konsumen pada merek rokok Djarum Super. Diponegoro Journal of Management. Vol. 1. No. 1. Hal 254-261

Tjiptono, Fandy. 2000. Strategi Bisnis. ANDI OFFSET. Yogyakarta.

Anwar, Iful. 2015. Pengaruh Harga dan Kualitas Produk terhadap Keputusan Pembelian, ( Jurnal Ilmu dan Riset Manajemen. Vol. 4. No. 12. Surabaya.

Kotler, Philip, dan Amstrong, Gary. 2014. Principle OfMarketing, $15^{\text {th }}$ edition.NewJersey: Prentice Hall.

Kotler, Philip dan Keller, K Lane. 2009. Manajemen Pemasaran. Edisi 13. Jilid 1 dan 2. Erlangga. Jakarta

Amir, M. Taufiq . 2005. Dinamika Pemasaran. PT RajaGrafindo Persada. Jakarta.

Winardi. 2010. Kepemimpinan dan Manajemen. PT Rineka Cipta. Jakarta.

Yanti, Fitri. 2017. Pengaruh Promosi dan Harga terhadap Keputusan Pembelian Viva Kosmetik pada Mahasiswi Fakultas Ekonomi dan BisnisUniversitas Muhammadiyah Palembang.

Yogie, Alfarishy. 2015. Pengaruh Kualitas Produk dan Harga Terhadap Keputusan Pembelian Minyak Rambut Pomade pada Mahasiswa Fakultas Ekonomi dan Bisnis Universitas Muhammadiayah Palembang. 